Majka Łojko*

\title{
EKONOMIA SPOŁECZNA WOBEC WYZWAŃ POLITYKI SPOŁECZNEJ - W POSZUKIWANIU WSPÓLNYCH RELACJI I PRZESTRZENI
}

\begin{abstract}
„Ekonomia społeczna proponuje aktywne formy pomocy zamiast pasywnych, współodpowiedzialność zamiast roszczeń i uzależnienia od pomocy, mobilizację obywatelską w miejsce rozbudowy systemu biurokratycznego [...] może być zatem istotnym sojusznikiem państwa w kształtowaniu i realizowaniu polityki społecznej".

Manifest Ekonomii Społecznej
\end{abstract}

\section{Wprowadzenie}

Ekonomia społeczna stanowi ważny element polityki społecznej. Jej podmioty są swoistego rodzaju spoiwem łączącym biznes, sektor publiczny i sektor pozarządowy, którego do tej pory w polskich realiach brakowało. Sektor ten, mimo że doświadcza wielu trudności w dostosowaniu się do wciąż zmieniającej się rzeczywistości polityczno-gospodarczej, posiada ogromny potencjał do zaspokajania wielu ważnych potrzeb państwa i społeczeństwa. Do jej atrybutów można z pewnością zaliczyć: przeciwdziałanie marginalizacji i wykluczeniu społecznemu, tworzenie stabilnych miejsc pracy, umiejętność dostarczania określonych usług społecznych oraz kształtowanie postaw przedsiębiorczych i odpowiedzialnych społecznie ${ }^{1}$.

Punktem wyjścia niniejszych rozważań jest pogląd, że ekonomia społeczna jest ważnym instrumentem, a zarazem elementem realizacji polityki społecznej o wielosektorowym charakterze. Analizując relacje pomiędzy tymi obszarami, nie sposób nie

* Wydział Nauk Społecznych, Uniwersytet Warmińsko-Mazurski w Olsztynie.

1 J. Brzozowska-Wabik, Potencjał spółdzielni w zaspokajaniu niektórych potrzeb państwa i społeczeństwa - wprowadzenie do dyskusji, „Ekonomia Społeczna” nr 2(5), 2012, s. 9. 
zauważyć, że oba posiadają odmienny zakres oraz dynamikę rozwoju, co sprawia, że ich relacji nie można jednoznacznie określać jako alternatywne lub komplementarne².

Celem artykułu jest opisanie kluczowych związków wyznaczających kierunki rozwoju ekonomii społecznej w przestrzeni polityki społecznej. Rozważania prowadzone zgodnie z przyjętymi założeniami podzielono na trzy części. W części pierwszej skoncentrowano się na określeniu miejsca ekonomii społecznej w polityce społecznej państwa. Następnie opisano przestrzenie i kierunki działań ekonomii społecznej w omawianym obszarze. Ostatnia część to próba ustalenia dalszych możliwości rozwoju ekonomii społecznej w obliczu aktualnych zadań polityki społecznej. Artykuł przygotowano w oparciu o literaturę, jak również o obowiązujące dokumenty programowe dotyczące ekonomii społecznej będące przykładami systemowych rozwiązań przyjmowanych w ramach polityki społecznej.

\section{Miejsce ekonomii społecznej w polityce społecznej}

Polityka społeczna na przełomie XX i XXI w. jest w ciągłym poszukiwaniu i ustalaniu jak najlepszego sposobu jej definiowania. Brak jednolitości w jej zdefiniowaniu spowodowany jest wieloaspektowością widzenia spraw kryjących się w tym określeniu ${ }^{3}$. Zdaniem R. Szarfenberga pojęcie polityki społecznej można analizować w dwojaki sposób. W pierwszym ujęciu szczególną uwagę poświęca się jej teoretycznym aspektom - w tym podejściu politykę społeczną należy rozumieć jako dyscyplinę teoretyczną. $Z$ drugiej strony polityka społeczna jest traktowana jako pewien obszar rzeczywistości i działalności praktycznej. ${ }^{4}$ Na potrzeby podjętej problematyki najbardziej adekwatnym wyborem definiowania polityki społecznej akcentującym wymiar jej prospołecznego działania wydaje się ujęcie A. Kurzynowskiego. Według autora „polityka społeczna to działalność państwa, samorządu i organizacji pozarządowych zmierzająca do kształtowania ogólnych warunków pracy i bytu ludności, prorozwojowych struktur społecznych oraz stosunków społecznych opartych

2 W. Goleński, Polityka społeczna i ekonomia społeczna. Kilka uwag o sprawiedliwości społecznej, „Ekonomia Społeczna” nr 2(7), 2013, s. 9, [za:] J. Orczyk, Ekonomia społeczna a polityka społeczna, [w:] Wokół ekonomii społecznej, red. M. Frączek, J. Hausner, S. Mazur, Małopolska Szkoła Administracji Publicznej, UE w Krakowie, Kraków 2012.

3 E. Kulesza, Lokalna polityka społeczna, Centrum Rozwoju Zasobów Ludzkich, Warszawa 2013, s. 7.

4 Por. R. Szarfenberg, Definicje polityki społecznej, http://rszarf.ips.uw.edu.pl/pdf/definicjeps.pdf [dostęp 24.11.2016]. 
na równości i sprawiedliwości społecznej, sprzyjających zaspokajaniu potrzeb społecznych na dostępnym poziomie"s.

W obliczu postępującego procesu gospodarczej i politycznej globalizacji Unii Europejskiej tradycyjny model opiekuńczy polityki społecznej staje się nieadekwatny wobec pojawiających się nowych kwestii społecznych ${ }^{6}$. Mino że tradycyjna polityka społeczna jest zorientowana na przeciwdziałanie wykluczeniu społecznemu, jej osiągnięcia w tej mierze są ograniczone. Główna przyczyna tego ograniczenia wynika z faktu, iż w analizowanym modelu beneficjentów postrzega się jako biernych odbiorców świadczeń/usług dostarczanych przez wyspecjalizowane grupy profesjonalistów, ograniczając tym samym ich aktywne uczestnictwo w procesie reintegracji .

Zdaniem J. Orczyka prowadzenie polityki społecznej, polegające na zwiększaniu zakresu świadczeń i usług o charakterze osłonowo-opiekuńczym, pod koniec XX w. zaczęło wywoływać liczne kontrowersje dotyczące sensowności takiego kierunku rozwoju. W prowadzonych w tym zakresie dyskusjach w szczególności akcentowano dwie sprawy:

- możliwość dalszego wzrostu udziału nakładów na cele społeczne (konsekwencją wzrostu kosztów finansowania świadczeń i usług społecznych stało się nadmierne obciążenie podatkowe, znacznie spowalniające tempo dostosowania gospodarki do zmian, które narzucała globalizacja);

- zwiększanie się liczby uprawnionych lub oczekujących pomocy w coraz bardziej dywersyfikujących się społecznościach (coraz trudniej było uzyskać zgodę na zwiększanie środków przeznaczanych na cele społeczne, następowała też pewna korekta postaw solidarnościowych na rzecz większej indywidualizacji ${ }^{8}$.

W obliczu wielu dylematów i zagrożeń zasadne było zredefiniowanie systemu polityki społecznej oraz wypracowanie nowego modelu jej działania. Zmiany w europejskiej polityce społecznej doprowadziły do ukonstytuowania się w poszczególnych państwach UE idei prowadzenia polityki społecznej określonej jako aktywna polityka społeczna (APS) ${ }^{9}$. ASP stanowi swoistego rodzaju koncepcję zmierzającą do reformy narzędzi i instrumentów aktywizacji zawodowej i społecznej, które umożliwią bardziej efektywne działania jednostek samorządu terytorialnego w zakresie

\footnotetext{
5 A. Kurzynowski, Zwiazki polityki społecznej z polityka gospodarcza, [w:] Polityka społeczna, red. A. Kurzynowski, Oficyna Wydawnicza SGH, Warszawa 2001, s. 11.

6 M. Grewiński, Ekonomia społeczna - pojęcia, uwarunkowania, dorobek międzynarodowy, [w:] Ekonomia społeczna - wybrane problemy i metody ich rozwiazywania, red. A. Austen-Tynda, Fundacja Regionalnej Agencji Promocji Zatrudnienia, Katowice 2009, s. 8.

7 T. Sadowski, Ekonomia społeczna $w$ Polsce - nowe perspektywy w przeciwdziałaniu wykluczeniu społecznemu, „Rynek Pracy” nr 3, 2005, s. 12.

8 J. Orczyk, op.cit., s. 180.

9 A. Karwacki, A. Glińska-Neweś, Innowacyjność w podmiotach ekonomii społecznej w Polsce. Studium jakościowe, „Ekonomia Społeczna” nr 2, 2015, s. 22.
} 
pomocy i integracji społecznej oraz budowy sektora usług społecznych ${ }^{10}$. Koncepcja ta stanowi przykład poszukiwania nowego modelu rozwiązań, który zastąpiłby tradycyjne podejście w polityce społecznej skoncentrowane przede wszystkim na zapewnieniu bezpieczeństwa socjalnego ${ }^{11}$. Głównym jej celem są działania aktywizujące i wszechstronnie wspierające jednostki i grupy społeczne zagrożone marginalizacją i wykluczeniem.

Przyjęcie koncepcji aktywnej oczywiście nie oznacza całkowitej rezygnacji z pomocy pasywnej, chodzi raczej o zmianę paradygmatu w działaniu. Aktywna polityka społeczna opiera się na działaniach akcentujących potrzebę inwestowania w kapitał ludzki, przy wykorzystaniu szerokiego wachlarza programów i instrumentów ${ }^{12}$.

Nowych możliwości rozwiązań problemów współczesnej polityki społecznej można upatrywać w ekonomii społecznej ${ }^{13}$. Samo pojęcie ekonomii społecznej jest wielowymiarowe i różnorodnie określane z uwagi na uwarunkowania społeczne, ekonomiczne, prawno-instytucjonalne i normatywne ${ }^{14}$. Dla dalszych rozważań istotne znaczenie ma definicja zaproponowana przez M. Grewińskiego, który ekonomię społeczną uznaje za „alternatywny w stosunku do państwowej polityki społecznej sposób rozwiązywania problemów społecznych, angażujący podmioty z różnych sektorów w celu zapewnienia większej spójności i integracji społecznej i osiągania bardziej skutecznych rezultatów przy wykorzystaniu metod partycypacji, odpowiedzialności i aktywizacji społecznej”15.

J. Hausner traktuje ekonomię społeczną jako segment podmiotów gospodarczych, usytuowanych w trójkącie państwo - rynek - społeczeństwo obywatelskie, przy czym ekonomia społeczna jest komplementarna w stosunku do rynku i państwa $^{16}$. Z założenia ma ona sprzyjać godzeniu odmiennych racjonalności przypisywanych rynkowi (racjonalność alokacyjna), państwu (racjonalność dystrybucyjna) i społeczeństwu (racjonalność solidarności). W tym kontekście ekonomia społeczna

10 http://rynekpracy.org/x/430423 [dostęp 20.11.2016].

11 M. Grewiński, Inwestycyjna polityka społeczna oparta na usługach - w kierunku nowego modelu welfare state?, [w:] Innowacyjna polityka społeczna, red. M. Grewiński, A. Karwacki, Wyższa Szkoła Pedagogiczna im. J. Korczaka, Warszawa 2015, s. 67.

12 M. Komorska, Strategie rozwoju polityki społecznej województwa lubelskiego na lata 2014-2010, „Polityka Społeczna" nr 10, 2014, s. 19.

13 Poza terminem „ekonomia społeczna” można spotkać się również z określeniami „przedsiębiorczość społeczna”, „gospodarka społeczna”, a także „gospodarka solidarna”. Nie ma jednoznacznego rozróżnienia między tymi terminami.

14 Regionalny Program Rozwoju Ekonomii Społecznej w województwie świętokrzyskim do roku 2020, Urząd Marszałkowski województwa świętokrzyskiego, ROPS, Kielce 2016, s. 5.

15 M. Grewiński, Ekonomia społeczna..., op.cit., s. 10.

16 M. Płonka, Ekonomia społeczna a koncepcje polityki społecznej państwa. Model polski, „Ekonomia Społeczna" nr 2, 2015, s. 85, [za:] J. Hausner, Ekonomia społeczna jako kategoria rozwoju, [w:] Ekonomia społeczna a rozwój, red. J. Hausner, Małopolska Szkoła Administracji Publicznej, UE w Krakowie, Kraków. 
doskonale wpisuje się w nurt polityki społecznej państwa w oparciu o koncepcje społeczno-ekonomiczne ${ }^{17}$.

Polityka społeczna i ekonomia społeczna to dziedziny pozostające ze sobą w ścisłym związku. Niemniej jednak w rozwiązywaniu problemów społecznych należy wskazać istotne pomiędzy nimi różnice, które można analizować w pięciu podstawowych wariantach (tab. 1).

Tabela 1. Różnice między ekonomią społeczną a polityką społeczną

\begin{tabular}{|l|l|l|}
\hline \multicolumn{1}{|c|}{ Wyszczególnienie } & \multicolumn{1}{c|}{ Ekonomia społeczna } & \multicolumn{1}{c|}{ Polityka społeczna } \\
\hline Dominujący stosunek własnościowy & własność prywatna & własność publiczna \\
\hline Dominujący sposób alokacji dóbr & rynkowy, nierynkowy & redystrybucyjny \\
\hline Dominujące źródła finansowania & prywatne & publiczne \\
\hline $\begin{array}{l}\text { Regulacja kierunków działań i jej } \\
\text { charakter }\end{array}$ & $\begin{array}{l}\text { dowolny, określony w statucie } \\
\text { organizacji }\end{array}$ & $\begin{array}{l}\text { ścisły, określony w ustawie } \\
\text { budżetowej }\end{array}$ \\
\hline $\begin{array}{l}\text { Charakter odpowiedzialności przed } \\
\text { społeczeństwem }\end{array}$ & ekonomiczny & polityczny \\
\hline
\end{tabular}

Źródło: M. Płonka, Ekonomia społeczna a koncepcje polityki społecznej państwa. Model polski, „Ekonomia Społeczna" nr 2, 2015, s. 94.

Poszukując odpowiedzi na pytanie o miejsce ekonomii społecznej w obszarze polityki społecznej, można wskazać na co najmniej kilka istotnych łączących je relacji: - ekonomia społeczna najczęściej traktowana jest jako wychodzenie podmiotów gospodarki społecznej na zewnątrz i skierowanie aktywności na beneficjentów oraz grupy klientów niebędących bezpośrednio członkami danej organizacji;

- sektor ekonomii społecznej występuje praktycznie we wszystkich gospodarkach, jednocześnie wypełniając luki w systemie polityki społecznej;

- zgodnie z założeniami Strategii Polityki Społecznej oraz Krajowego Programu Rozwoju Ekonomii Społecznej ekonomia społeczna stanowi ważny czynnik wzrostu zatrudnienia, spójności społecznej oraz rozwoju kapitału społecznego;

- instytucje ekonomii społecznej jako podmioty gospodarcze i społeczne działają we wspólnotach samorządowych, tym samym dostarczają usług użyteczności publicznej;

- ekonomia społeczna (zwłaszcza jej podmioty) jest ważnym elementem gospodarki, wnosząc do niej korzyści ekonomiczne, społeczne i środowiskowe;

- zaspokajanie potrzeb społecznych nie jest główną domeną instytucji ekonomii i polityki społecznej; ich zadaniem jest aktywne pomaganie w tworzeniu

17 A. Kożuch, E. Książek, Spółdzielnia socjalna jako forma przedsiębiorstwa społecznego, „Pragmata Tes Oikonomias”, „Prace Naukowe Akademii im. Jana Długosza w Częstochowie” z. VIII, 2014, s. 182. 
odpowiednich warunków do zaspokajania potrzeb w ramach realizowanych programów ${ }^{18}$.

W tym miejscu pojawia się pytanie o pożytki, jakie czerpie polityka społeczna z ekonomii społecznej. Istnieją co najmniej cztery fundamentalne wymiary owych korzyści:

- podmiotowy: koncentracja na indywidualnych potrzebach osób i grup z deficytami społecznymi (budowa kapitału ludzkiego w grupach defaworyzowanych);

- rynkowy: ukierunkowanie na stosowanie reguł ekonomicznych, finansowa samodzielność;

- aktywizacyjny: nastawienie na budzenie potencjału aktywności i powrót do aktywności (i do pracy);

- kooperatywny: bycie we wspólnocie, poczucie wsparcia grupy (solidarność społeczna) $)^{19}$.

Problematyka ekonomii społecznej obejmuje wiele dziedzin odnoszących się nie tylko do sfery polityki społecznej. W wytycznych ministra pracy i polityki społecznej ${ }^{20}$ podkreślono potrzebę usytuowania ekonomii społecznej w opracowywanych strategiach rozwoju województw, które są podstawowym narzędziem polityki regionalnej prowadzonej przez samorządy poszczególnych województw. Plany działań na rzecz promocji i upowszechniania ekonomii społecznej oraz rozwoju instytucji sektora ekonomii społecznej powinny stanowić programy wojewódzkie w zakresie rozwoju ekonomii społecznej, które w swoich zapisach muszą odwoływać się do priorytetów wojewódzkiej strategii polityki społecznej ${ }^{21}$; w zakresie funkcjonalnym - jakie funkcje może realizować sektor ekonomii społecznej w regionie, w zakresie instytucjonalnym - rozwój społeczeństwa obywatelskiego, rozwój ekonomii społeczneje22.

Niewątpliwie ten sposób gospodarowania wzmacnia kapitał społeczny, odtwarza lokalną przestrzeń publiczną i sprzyja urzeczywistnieniu idei obywatelskości.

18 M. Grewiński, S. Kamiński, Obywatelska polityka społeczna, WSP-TWP, Warszawa 2007, s. 170.

19 Wymiary korzyści podaję za: M. Boni, Ekonomia społeczna - nowe szanse?, http://www.ekonomiaspoleczna.pl/x/436283\#p) [dostęp 5.12.2016].

20 Wytyczne Ministra Pracy i Polityki Społecznej z dnia 17 maja 2011 r. do przygotowania i realizacji wieloletniego regionalnego planu działań na rzecz promocji i upowszechnienia ekonomii społecznej oraz rozwoju instytucji sektora ekonomii społecznej i jej otoczenia w regionie.

21 Strategia polityki społecznej województwa jest kluczowym dokumentem programowym i istotnym narzędziem realizacji regionalnej polityki społecznej, wyznaczającym priorytety, cele i działania na rzecz rozwiązywania problemów społecznych.

22 Porównanie koncepcji wsparcia rozwoju ekonomii społecznej na poziomie regionalnym i krajowym na podstawie wieloletnich regionalnych planów działań na rzecz promocji i upowszechnienia ekonomii spotecznej oraz rozwoju instytucji sektora ekonomii społecznej i jej otoczenia w regionie oraz projektu Krajowego Programu Rozwoju Ekonomii Społecznej, Ekspertyza, Szczecin 2013, s. 9. 
Ponadto służy reformowaniu sektora usług publicznych, stanowiąc element wzrostu zatrudnienia i wzmacniania procesu integracji społecznej ${ }^{23}$.

\section{Funkcje i przestrzenie działań ekonomii społecznej}

Istotnym punktem dalszych rozważań jest określenie funkcji i kierunków działań instytucji ekonomii społecznej w przestrzeni polityki społecznej. Instytucje te są podmiotami gospodarczymi i społecznymi działającymi praktycznie we wszystkich obszarach i dziedzinach. Przez lata rozwijało się wiele podmiotów ekonomii społecznej należących do tzw. starej ekonomii społecznej, są to: stowarzyszenia, fundacje prowadzące działalność gospodarczą lub odpłatną działalność pożytku publicznego, towarzystwa ubezpieczeń wzajemnych, tworzące trzeci sektor nazywane są tradycyjną ekonomią społeczną ${ }^{24}$. Z kolei powstające aktualnie typy podmiotów, takie jak spółdzielnie socjalne, przedsiębiorstwa społeczne, centra integracji społecznej, zakłady aktywności zawodowej, warsztaty terapii zajęciowej, określane są jako nowa ekonomia społeczna, której działania skoncentrowane są przede wszystkim na integracji zawodowej osób zagrożonych wykluczeniem społecznym ${ }^{25}$.

Funkcją podmiotów ekonomii społecznej jest nie tylko wytwarzanie określonych dóbr i usług, ale też mobilizacja kapitału społecznego, generowanie innowacyjności oraz poszerzanie rynku przez włączanie do uczestnictwa w nim osób dotychczas wykluczonych ${ }^{26}$. Zarówno mnogość form prawnych, jak i specyficzny charakter działania przedsiębiorstw ekonomii społecznej nie pozwala na jednoznaczne zdefiniowanie analizowanego obszaru. Brak jednoznaczności w definiowaniu i możliwości zamknięcia całego obszaru w jednej konstrukcji formalnej stanowi główny atrybut sektora, a zarazem konceptualno-intelektualne wyzwanie dla badaczy i decydentów. Owa amorficzność ułatwia mu dopasowywanie się do zmieniającej się

23 J. Filek, Ekonomia społeczna jako nowe wyzwanie, „Annales. Etyka w życiu gospodarczym” vol. 12, nr 1, 2009, s. 186.

24 Określeniem „tradycyjna ekonomia społeczna” przyjęło się nazywać zakorzenione w tradycji europejskiej formy wspólnego gospodarowania.

25 Jeżeli chodzi o sposób finansowania, to podmioty starej ekonomii (tradycyjnej) społecznej niemal nie różnią się pod tym względem od przedsiębiorstw komercyjnych: przychody pochodzą z działalności rynkowej. Natomiast podmioty nowej ekonomii społecznej (których znaczna część powstaje w wyniku podjęcia działalności gospodarczej przez organizacje pozarządowe) przychody czerpią zarówno ze sprzedaży usług lub produktów na wolnym rynku, jak i z dotacji oraz darowizn.

26 A. Balcewicz, Wartość dodana generowana przez podmioty ekonomii społecznej - korzyści ekonomiczne i społeczne, „Współczesne Problemy Ekonomiczne” nr 11, 2015, s. 108. 
rzeczywistości społecznej. Cecha ta, odpowiednio zdefiniowana i zagospodarowana, może stanowić o sile nie tylko sektora, ale również polityki społecznej ${ }^{27}$.

K. Wygnański i P. Frączak uważają, „że ekonomia społeczna stanowi [...] przestrzeń, sposób komunikacji między uczestnikami, możliwość mobilizowania różnorodnych zasobów, raczej dostęp do dóbr niż ich posiadanie"28. W zależności od przestrzeni i sposobów działania należy wyodrębnić jej trzy podstawowe filary; są to:

1) Działalność gospodarcza, której cele społeczne przeważają nad chęcią maksymalizacji zysków. Działalność ta jest weryfikowana przez rynek, niemniej jednak cele ekonomiczne nie są pierwszoplanowe. Ważniejsze są tu cele społeczne zakładanych przedsiębiorstw, zaś ewentualne zyski z działalności są przeznaczone na urzeczywistnianie założonych celów społecznych.

2) Aktywizacja społeczności lokalnej i budowanie solidarności społecznej jako instrument integracji społecznej.

3) Praca jako dobro kulturowe, tj. antidotum na bierność zawodową i destrukcję społeczną wynikającą z bezrobocia. Prowadzi to do akceptacji zatrudnienia socjalnego, którego celem jest nie tylko praca zarobkowa, ale też aktywność prowadząca do odzyskania zdolności zatrudnienia na otwartym rynku pracy ${ }^{29}$. Zasadniczo w sferze ekonomii społecznej działają podmioty obejmujące cztery główne grupy:

1) Przedsiębiorstwa społeczne, będące fundamentem ekonomii społecznej i prowadzące działalność gospodarczą, która wyznacza sobie cele społeczne i inwestuje wypracowane nadwyżki w działalność lub we wspólnotę, zamiast kierować się potrzebą osiągania maksymalnego zysku na rzecz akcjonariuszy lub właścicieli ${ }^{30}$. Pełnią szereg funkcji, które można sprowadzić do wspólnego mianownika, nazywając je celami ukierunkowanymi na rozwój kapitału społecznego społeczności lokalnych oraz samych instytucji ekonomii społecznej ${ }^{31}$.

27 M. Frączek, N. Laurisz, Ekonomia społeczna a rynek pracy, [w:] Wokół ekonomii społecznej, red. M. Frączek, J. Hausner, S. Mazur, Małopolska Szkoła Administracji Publicznej, UE w Krakowie, Kraków 2012, s. 164.

28 K. Wygnański, P. Frączak, Ekonomia spoleczna w Polsce - definicje, zastosowania, oczekiwania, wątpliwości, „Ekonomia Społeczna. Teksty” nr 1, 2006, s. 32.

29 W. Toczyski, Niezborności ekonomii społecznej? Rola i miejsce ekonomii społecznej w programach operacyjnych, „Trzeci Sektor” nr 9, 2007, s. 37-38.

30 Zgodnie z Rozporządzeniem Parlamentu Europejskiego i Rady w sprawie Programu Unii Europejskiej na rzecz Przemian i Innowacji Społecznych przedsiębiorstwo społeczne oznacza przedsiębiorstwo, którego głównym celem jest raczej wywarcie wpływu społecznego niż wygenerowanie zysków dla właścicieli i zainteresowanych stron. Działa ono na rynku, produkując towary i świadcząc usługi w innowacyjny sposób zgodny z duchem przedsiębiorczości, a także wykorzystuje nadwyżki przede wszystkim do osiągania celów społecznych. Jest zarządzane w odpowiedzialny i przejrzysty sposób, w szczególności poprzez angażowanie pracowników, klientów i zainteresowanych stron, których dotyczy działalność gospodarcza przedsiębiorstwa.

31 M. Jelonek, Teorie socjologiczne a ekonomia społeczna, [w:] Wokót ekonomii społecznej, red. M. Frączek, J. Hausner, S. Mazur, UE w Krakowie, Kraków 2012, s. 63. 
2) Podmioty reintegracyjne, służące reintegracji społecznej i zawodowej osób zagrożonych wykluczeniem społecznym, m.in. zakłady aktywności zawodowej, warsztaty terapii zajęciowej, centra integracji społecznej. Formy te nie są przedsiębiorstwami społecznymi, mogą być prowadzone jako usługa na rzecz społeczności lokalnej.

3) Podmioty sfery pożytku publicznego, które prowadzą działalność ekonomiczną, zatrudniają pracowników, niemniej jednak ich działanie nie jest oparte na ryzyku ekonomicznym. Są to organizacje pozarządowe prowadzące działalność odpłatną i nieodpłatną pożytku publicznego. Podmioty te mogą stać się przedsiębiorstwami społecznymi, o ile rozpoczną działalność gospodarczą w określonym zakresie, podejmując również zobowiązania statutowe dotyczące dystrybucji zysku.

4) Podmioty sfery gospodarczej, które tworzone są w związku z urzeczywistnianiem celu społecznego. Są to podmioty, które nie spełniają wszystkich cech i warunków dotyczących działalności przedsiębiorstwa społecznego ${ }^{32}$.

Funkcję ekonomii społecznej należy także analizować w perspektywie koncepcji aktywnej polityki społecznej. Istnieje co najmniej kilka istotnych przesłanek wskazujących na to, że ekonomia społeczna stanowi jeden z najważniejszych komponentów nowej polityki społecznej. „Po pierwsze, znakomicie wkomponowuje się w ideę budowania demokracji uczestniczącej poprzez nową wizję ładu społecznego oraz integrację społeczności lokalnych. Po drugie, [...] może stanowić istotny element polityki wzrostu zatrudnienia poprzez wypełnianie przestrzeni lokalnej w sferze usług społecznych oraz umożliwienie zatrudnienia grup szczególnie zagrożonych na rynku (niepełnosprawni, długotrwale bezrobotni). Po trzecie, [...] stanowi również istotny instrument procesu integracji społecznej, kreujący przewartościowanie ról zawodowych i społecznych (budowanie wspólnot opartych na solidarności, nie na zależności) oraz stanowi reakcję na praktyczne urzeczywistnianie idei prymitywnie pojmowanego workfare state (dobrowolność podejmowanych działań zamiast restrykcji związanych z przymusem aktywizacyjnym)"33.

Należy podkreślić, że nadrzędnym zadaniem ekonomii społecznej jest wypełnianie funkcji prorozwojowych, czyli ${ }^{34}$ :

32 K. Herbst, Perspektywy ekonomii społecznej, „Ekonomia Społeczna” nr (6), 2013, s. 14-15.

33 C. Miżejewski, Polityka społeczna wobec sektora ekonomii społecznej, [w:] Raport otwarcia projektu „W poszukiwaniu polskiego modelu ekonomii społecznej”, FISE, Warszawa 2006, s. 5.

34 J. Hausner, Ekonomia społeczna. Konceptualizacja, [w:] Ekonomia społeczna a publiczne stużby zatrudnienia w Polsce - zasady, perspektywy i kierunki współpracy, red. S. Mazur, A. Pacut, FISE, Warszawa 2008, s. 20, [za:] M. Woolcock, Social Capital and Economic Development: Towards a Theoretical Synthesis and Policy Framework, „Theory and Society” Vol. 27, 1998; J. Defourny, M. Simon, S. Adam, The Co-operative Movement in Belgium: Perspectives and Prospects, Editions Luc Pire 2002; Social Enterprise. A Strategy for Success, Department of Trade and Industry, London 2002 (www.dti.gov.uk/socialenterprise/strategy.htm). 
- tworzenie materialnej bazy dla działania organizacji obywatelskich,

- promocja alternatywnych form kredytowania,

- wzmacnianie kapitału społecznego,

- regeneracja lokalnej przestrzeni publicznej,

- urzeczywistnianie idei obywatelskości,

- reformowanie sektora usług publicznych ${ }^{35}$.

Łącząc funkcje prorozwojowe z rolą społecznego przedsiębiorcy, ekonomia w krótkim okresie tworzy miejsca pracy, dając oszczędności w wydatkach publicznych w średnim okresie, wprowadza rozwiązania reformujące tradycyjne państwo opiekuńcze, w długim okresie natomiast kreuje i spożytkowuje kapitał społeczny ${ }^{36}$.

Podmioty ekonomii społecznej działając $\mathrm{w}$ różnych obszarach gospodarki, poprzez dostarczanie obywatelom niedrogich usług użyteczności publicznej stanowią instrument procesu integracji i rozwoju społeczności lokalnej ${ }^{37}$. Katalog podmiotów i form prawnych jak również wachlarz podejmowanych działań jest szeroki - w zależności od wyboru branży, służy rozwiązywaniu kwestii polityki społecznej. W dłuższej perspektywie podmioty ekonomii społecznej mają szansę stać się głównymi wykonawcami dostępnych, dobrze świadczonych i tanich usług społecznych. Istotnym obszarem może również stać się segment usług niszowych, mniej opłacalnych dla biznesu ${ }^{38}$. Poszukując nisz, w których podmioty ekonomii społecznej miałyby największe szanse rozwoju, należy wskazać kilka cech, jakimi powinny się one charakteryzować:

- Niezbyt zyskowne. Przedsiębiorstwa społeczne mają większe szanse tam, gdzie przewidywany zysk jest stosunkowo niski. Niejednokrotnie przedsiębiorstwa społeczne mogą konkurować na wolnym rynku - w przeciwieństwie do firm komercyjnych, bezpośredni zysk finansowy nie jest w tym przypadku najważniejszy. Z tego też względu tam, gdzie ten zysk jest niewielki lub go praktycznie nie ma, istnieje realna szansa rozwoju przedsiębiorstw społecznych.

- Niskonakładowe. Niewielka stopa zwrotu (zysk) wiąże się często z faktem, iż przedsiębiorstwa społeczne nie posiadają środków na inwestycje (nie kapitał, ale pomysł ma tutaj większe znaczenie). Natomiast przedsiębiorstwa rynkowe nie wchodzą w inwestycje, które nie przynoszą wystarczających zysków, szczególnie jeżeli trzeba zaryzykować opłacenie pracy w sytuacji, gdy efekt nie jest pewny.

35 J. Hausner, Ekonomia społeczna. Konceptualizacja, op.cit., s. 21-22.

36 J. Hausner, Ekonomia społeczna jako kategoria rozwoju, [w:] Ekonomia społeczna a rozwój, red. J. Hausner, Małopolska Szkoła Administracji Publicznej, UE w Krakowie, Kraków 2009, s. 15.

37 Krajowy Program Rozwoju Ekonomii Społecznej. Projekt, Warszawa 2012, s. 7.

38 Ekonomia społeczna (broszura informacyjna), ROPS, Katowice 2013, s. 10. 
- Wzajemnościowe. Oparcie się na stosunkach wzajemnych, zarówno wewnątrz przedsiębiorstwa, jak i w stosunkach z klientami, jest szansą na zapewnienie stałych zleceń. Umożliwienie wszystkim interesariuszom włączenia się w realizowanie wspólnego przedsięwzięcia, danie im poczucia współwłasności i współdecydowania może spowodować, że koszty przedsiębiorstwa będą niższe, a ono samo bardziej rentowne.

- Specyficzne. Zatrudnianie lub współpraca z osobami wyjątkowymi ${ }^{39}$ powoduje konieczność wydobycia ich specyficznych umiejętności oraz odpowiednie ich zastosowanie. To, co często przeszkadza w realizacji czysto komercyjnego biznesu, może być zaletą przedsiębiorstw społecznych ${ }^{40}$.

Kluczem do sukcesu podmiotów ekonomii społecznej jest spojrzenie na przedsiębiorstwo społeczne jako na element szerszej sieci podmiotów publicznych, prywatnych i pozarządowych. Włączenie tych podmiotów do istniejących powiązań kooperacyjnych może okazać się dużo stabilniejszą i skuteczniejszą strategią marketingową niż samodzielne poszukiwanie swojego miejsca na rynku. Aby jednak było to możliwe, niezbędna jest identyfikacja takich sieci i powiązań rynkowych, w które mogą włączyć się przedsiębiorstwa i, co więcej, włączenie to będzie opłacalne zarówno dla samych podmiotów gospodarki społecznej, jak i dla pozostałych partnerów w ramach istniejących powiązań. Dlatego też jednym z instrumentów zwiększających szanse na zapewnienie trwałych podstaw działania jest umiejscowienie ich w łańcuchu wartości wytwarzanych na poziomie lokalnym i regionalnym, czyli budowanie jego pozycji na bazie współpracy biznesowej z miejscowymi przedsiębiorcami, samorządem lokalnym i lokalną społecznością ${ }^{41}$. W związku z tym ekonomia społeczna powinna stanowić nieodłączny element polityki społecznej gmin i powiatów. Lokalne władze mogą zlecać do realizacji zadania, wykorzystując na przykład tzw. klauzule społeczne w zamówieniach publicznych, dające preferencje wykonawcom zatrudniającym osoby wykluczone z rynku pracy. Mogą też zapewniać wsparcie doradcze

39 Np. zgodnie z nowelizacją Ustawy z dnia 27 kwietnia 2006 r. o spółdzielniach socjalnych z sierpnia 2015 r. w kręgu osób fizycznych, uprawnionych do tworzenia podmiotów ekonomii społecznej takich jak spółdzielnie socjalne są osoby bezrobotne, absolwenci Centrów Integracji Społecznej (CIS) i Klubów Integracji Społecznej (KIS); osoby niepełnosprawne; osoby do 30 roku życia oraz po ukończeniu 50 roku życia, posiadające status osoby poszukującej pracy, bez zatrudnienia.

40 Nisze rynkowe $w$ obszarze współpracy podmiotów ekonomii społecznej i jednostek samorządu terytorialnego w powiecie braniewskim - raport z badań, red. M. Łojko, OWIES, Elbląg 2014, s. 8-9, [za:] P. Frączak, Możliwe obszary ekspansji podmiotów ekonomii społecznej - propozycje rekomendacji, Przedsiębiorstwo ekonomii społecznej z sukcesem - projekt promocji dobrych praktyk, Projekt współfinansowany przez Unię Europejską w ramach Europejskiego Funduszu Społecznego.

41 Badanie obszarów działalności gospodarczej (branż) dostępnych i atrakcyjnych dla podmiotów ekonomii społecznej w województwie wielkopolskim. Raport końcowy, Regionalny Ośrodek Polityki Społecznej, Poznań 2011, s. 11. 
i szkoleniowe, infrastrukturalne (np. bezpłatne użyczenie lokalu czy gruntu, utworzenie inkubatora, ułatwienie kontaktu z sektorem biznesu i wspomaganie promocji). Zaangażowany samorząd - wraz z podległymi jednostkami organizacyjnymi (m.in. ośrodki pomocy społecznej, powiatowe urzędy pracy) - może inicjować i zachęcać do tworzenia takich podmiotów społecznych na terenie swojego działania ${ }^{42}$.

\section{Ekonomia społeczna w pespektywie dalszych wyzwań polityki społecznej}

Nie sposób nie zauważyć, iż pomiędzy obszarami ekonomii społecznej i polityki społecznej istnieją silne powiązania konceptualne i logiczne współzależności. W kontekście działań w zakresie przeciwdziałania wykluczeniu i marginalizacji społecznej wydaje się, że aktywizujące metody i partycypacyjny charakter działań ekonomii społecznej mają istotne znaczenie. Niemniej jednak na tym etapie rozwoju trudno jednoznacznie określić, jaki może być realny wpływ podmiotów gospodarki społecznej na niwelowanie kwestii społecznych. Czy rzeczywiście będzie to nowa jakość polityki społecznej? Obecnie temat ekonomii społecznej stał się przedmiotem zainteresowania ekspertów, badaczy, przedstawicieli administracji publicznej i liderów społeczeństwa obywatelskiego. Szczególnie skuteczność działania instytucji ekonomii społecznej w Polsce powinna być przedmiotem dalszych szczegółowych badań, nie wszystkie bowiem rozwiązania, które sprawdziły się gdzie indziej, można przenieść i skutecznie zaimplementować $\mathrm{w}$ innym otoczeniu. Jeśli jednak przedsiębiorczość społeczna okaże się skutecznym i szeroko akceptowanym narzędziem polityki społecznej, będzie to oznaczało konieczność przeorientowania myślenia o rozwiązywaniu kwestii społecznych w kierunku wsparcia wielosektorowej i obywatelskiej polityki społecznej ${ }^{43}$.

Ekonomia społeczna w postaci funkcjonujących podmiotów gospodarczych nie może uciec od podstawowych reguł rynkowych: równej konkurencyjności, potrzeby istnienia zgodnie z zasadą samofinansowania, konieczności zdobywania rynku, pomysłów biznesowych i kreatywności w ich tworzeniu. Subsydiowanie zatrudnienia osób pracujących w podmiotach ekonomii społecznej może znacznie ułatwić rozwój tych podmiotów, ale nie zdejmie z nich i ich liderów obowiązku kontroli kosztów,

42 Ekonomia społeczna (broszura informacyjna), op.cit., s. 12.

43 M. Grewiński, Gospodarka społeczna jako element obywatelskiej polityki społecznej, [w:] Obywatelska polityka społeczna, red. M. Grewiński, S. Kamiński, WSP-TWP, Warszawa 2007, s. 191. 
konkurencyjnej oferty pod względem jakości, nowoczesnych rozwiązań marketingowych. Ekonomia społeczna, choć nienastawiona na zysk, nie może uciekać od możliwości tworzenia nadwyżek, które byłyby przeznaczane na przyszłościowe inwestycje np. w formule spółdzielczej - zgodnie z decyzją wszystkich właścicieli44 ${ }^{4}$.

Zgodnie z założeniami Krajowego Programu Rozwoju Ekonomii Społecznej działania w tym obszarze powinny opierać się na trzech zintegrowanych priorytetach (impulsach rozwojowych): politycznym, społecznym i przedsiębiorczym. Priorytety i zaplanowane kierunki działań zaprezentowano w tabeli 2.

Tabela 2. Priorytety działań w obszarze ekonomii społecznej według KPRES

\begin{tabular}{|c|c|}
\hline Priorytet & Założone kierunki działań \\
\hline Polityczny & $\begin{array}{l}\text { Tworzenie przyjaznego klimatu dla ekonomii społecznej. Wynika to z potrzeby większego otwarcia } \\
\text { się administracji publicznej na sektor ekonomii społecznej; tym postuluje się konieczność } \\
\text { wprowadzenia zmian w tym zakresie. Proponuje się także zmianę podejścia do partycypacji } \\
\text { w zakresie kreowania i realizowania polityki publicznej z udziałem podmiotów ekonomii społecznej, } \\
\text { które powinny mieć względne pierwszeństwo jako pracodawcy we wspólnotach samorządowych, } \\
\text { działający nie dla zysku, mający zakorzenione struktury w lokalnym środowisku i działający } \\
\text { w opacciu o społeczne zasoby. }\end{array}$ \\
\hline Społeczny & $\begin{array}{l}\text { Działania publiczne mogą tworzyć przestrzeń prawna, organizacyjną i finansową dla podmiotów } \\
\text { ekonomii społecznej. Jednakże bez uruchomienia potencjału społecznego praktycznie niemożliwe } \\
\text { jest wdrożenie powszechnie uznanych i akceptowanych działań w ramach polityki publicznej. } \\
\text { Partycypacja ma sens o tyle, o ile zaangażowane są właściwe, zainteresowane w partnerstwie strony. }\end{array}$ \\
\hline Przedsiębiorczy & $\begin{array}{l}\text { Umożliwienie znalezienia miejsca dla kompetencji i społecznie użytecznych funkcji ekonomii } \\
\text { społecznej w sektorze szeroko rozumianej przedsiębiorczości. Dotychczasowym mankamentem } \\
\text { ekonomii społecznej była zbyt słaba promocja przedsiebbiorczości, rozumianej jako szczególny } \\
\text { sposób produkcji dóbr i świadczenia usług, a w konsekwencji tworzenia miejsc pracy, przynoszący } \\
\text { także wymierną społeczną wartość dodaną. }\end{array}$ \\
\hline
\end{tabular}

Źródło: Opracowanie własne na podstawie Krajowego Programu Rozwoju Ekonomii Społecznej, MPiPS, Warszawa 2014, s. 26.

J. Hausner uważa, że wsparcie rozwoju ekonomii społecznej powinno przebiegać w pięciu sferach:

- integracji - ukierunkowanej na wspieranie działań na rzecz stworzenia platform instytucji ekonomii społecznej i organizacji wspierających jej rozwój (w tym współpracy sektora społecznego i tradycyjnych partnerów społecznych);

- infrastruktury - wzmocnienie systemu doradztwa i informacji dla inicjatyw ekonomii społecznej;

- dostępu do kapitału - rozwój regionalnych i lokalnych funduszy pożyczkowych i grantowych ekonomii społecznej;

- pomocy publicznej - określenie jasnych zasad pomocy publicznej dla inicjatyw ekonomii społecznej;

44 M. Boni, Ekonomia społeczna - szanse i pokusy, „Ekonomia Społeczna” nr 1(1), 2007, s. 53. 
- edukacyjnej - promocja działań ekonomii społecznej i partnerstwa publiczno-społecznego ${ }^{45}$.

Niewątpliwie ekonomia społeczna stanowi kluczowy element w społecznym rozwoju lokalnym oraz sprzyja tworzeniu społeczeństwa obywatelskiego. Jej działania wpisują się w propagowane przez Unię Europejską cele, takie jak: spójność społeczna, pełne zatrudnienie, walka $\mathrm{z}$ ubóstwem i biedą, przeciwdziałanie dyskryminacji, budowanie podstaw demokracji uczestniczącej, poprawa zarządzania w lokalnym środowisku czy też stabilny rozwój ${ }^{46}$. Będąc otwartym segmentem gospodarki, może sprzyjać spójności społecznej. Z tego też względu powinna być ona traktowana jako komplementarny sektor w nowoczesnej gospodarce, będący istotnym czynnikiem i stymulatorem innowacyjności rozwoju ${ }^{47}$.

\section{Podsumowanie}

Zaprezentowany w artykule dyskurs wskazuje kluczowe związki wyznaczające kierunki rozwoju ekonomii społecznej w przestrzeni polityki społecznej, traktując ekonomię społeczną jako jej element uzupełniający. Podjęte rozważania pokazują, że ekonomia społeczna na trwałe wpisała się w sferę działań polityki społecznej w zakresie rozwiązywania trudnych kwestii. We współczesnej polityce społecznej istnieje określona przestrzeń dla inicjatyw i kierunków jej działań. Pomimo rosnącego znaczenia sektora ekonomii społecznej w polityce społecznej nie powinno się jej rozpatrywać jako kluczowej instytucji polityki społecznej, bądź też jako panaceum na rozwiązywanie wszelkich kwestii społecznych. Należy ją raczej analizować jako sektor uzupełniający działania polityki społecznej państwa w odniesieniu do istniejących problemów społecznych. Z jednej strony ekonomia społeczna powinna być traktowana jako kategoria rozwoju, przez co może przyczyniać się do modyfikacji zachowań rynkowych czy też politycznych; z drugiej strony nie należy w niej upatrywać źródła nowego porządku ${ }^{48}$.

W prowadzonej dyskusji nad koncepcją ekonomii społecznej wciąż pojawia się wiele dylematów i wyzwań. Na pierwszy plan wysuwają się pytania o przyszły charakter

45 C. Miżejewski, Polityka społeczna wobec sektora ekonomii społecznej, „Ekonomia Społeczna. Teksty” nr 21, 2006, s. 12.

46 I. Łącka, Problemy oceny efektywności podmiotów ekonomii społecznej, „Prace Naukowe UE we Wrocławiu" nr 395, 2015, s. 242.

47 J. Lewandowska-Bratek, Wspótczesna gospodarka społeczna jako odpowiedź na niezaspokojone potrzeby społeczne Polaków, „Studia Oeconomica Posnaniensia” nr 7(3), 2015, s. 43.

48 J. Hausner, Ekonomia społeczna jako sektor gospodarki, „Ekonomia Społeczna” nr 1, 2007, s. 13. 
i przestrzeń dla współpracy działań z obszaru gospodarki społecznej z gospodarką rozumianą tradycyjnie, jak również o zakres zależności i wsparcia podmiotów ekonomii społecznej ze strony polityki społecznej ${ }^{49}$.

Należy uznać, iż ekonomia społeczna jest jednym z najistotniejszych pojęć dotyczących polityki rozwiązywania problemów społecznych. Tak duże zainteresowanie wywołane jest szczególnie ze względu na występujące odgórne działania zapisane w unijnych i krajowych dokumentach strategicznych. Zakłada się, iż dzięki tym zapisom nastąpi wzrost spójności społecznej, stworzonych zostanie więcej wartościowych miejsc pracy i ograniczy się obszar wykluczenia społecznego. Jednakże do rozwoju ekonomii społecznej niezbędne jest oddolne zaangażowanie, którego wciąż brakuje, a koncepcje i działania powoli pojawiają się w świadomości przedsiębiorców lokalnych, samorządowców oraz organizacji społecznych. Ekonomia społeczna ze swoim naciskiem na wartości społeczne zdecydowanie powinna być wykorzystywana do przeprowadzania wnikliwej analizy współczesnej polityki społecznej, jej problemów, wyzwań i sposobów działania. Konieczne jest zatem tworzenie zintegrowanych i komplementarnych działań w oparciu o spójny model ekonomii i polityki społecznej uwzględniający zarówno aspekty ekonomiczne, społeczne, jak i kulturowe.

Warto jeszcze raz podkreślić, że związki pomiędzy polityką i ekonomią społeczną mają charakter obustronny. Dziedziny te wzajemnie się przenikają, nieustannie uzupełniają, inspirując się nawzajem. Nakreślona w artykule wspólna perspektywa relacji i przestrzeni obu obszarów nie ma charakteru skończonego. Przedmiotem dalszej dyskusji powinna stać się wzajemna relacja w zakresie powierzania i realizacji zadań polityki społecznej przez sektor ekonomii społecznej.

\section{Literatura}

Badanie obszarów działalności gospodarczej (branż) dostępnych i atrakcyjnych dla podmiotów ekonomii społecznej w województwie wielkopolskim. Raport końcowy, Regionalny Ośrodek Polityki Społecznej, Poznań 2011.

Balcewicz A., Wartość dodana generowana przez podmioty ekonomii społecznej - korzyści ekonomiczne i społeczne, „Współczesne Problemy Ekonomiczne” nr 11, 2015.

Boni M., Ekonomia społeczna - nowe szanse?, http: //www.ekonomiaspoleczna.pl/x/436283\#p)

Boni M., Ekonomia społeczna - szanse i pokusy, „Ekonomia Społeczna” nr 1(1), 2007.

49 J. Filek, op.cit., s. 187. 
Brzozowska-Wabik J., Potencjał spółdzielni w zaspokajaniu niektórych potrzeb państwa i społeczeństwa - wprowadzenie do dyskusji, „Ekonomia Społeczna” nr 2(5), 2012.

Ekonomia społeczna (broszura informacyjna), ROPS, Katowice 2013.

Filek J., Ekonomia społeczna jako nowe wyzwanie, „Annales. Etyka w życiu gospodarczym” vol. 12, $\mathrm{nr} 1,2009$.

Frączek M., Laurisz N., Ekonomia społeczna a rynek pracy, [w:] Wokót ekonomii społecznej, red. M. Frączek, J. Hausner, S. Mazur, Małopolska Szkoła Administracji Publicznej, UE w Krakowie, Kraków 2012.

Goleński W., Polityka społeczna i ekonomia społeczna. Kilka uwag o sprawiedliwości spoŁecznej, „Ekonomia Społeczna” nr 2(7), 2013.

Grewiński M., Ekonomia społeczna - pojęcia, uwarunkowania, dorobek międzynarodowy, [w:] Ekonomia społeczna - wybrane problemy i metody ich rozwiazywania, red. A. Austen-Tynda, Fundacja Regionalnej Agencji Promocji Zatrudnienia, Katowice 2009.

Grewiński M., Gospodarka społeczna jako element obywatelskiej polityki społecznej, [w:] Obywatelska polityka społeczna, red. M. Grewiński, S. Kamiński, WSP-TWP, Warszawa 2007.

Grewiński M., Inwestycyjna polityka społeczna oparta na usługach - w kierunku nowego modelu welfare state?, [w:] Innowacyjna polityka społeczna, red. M. Grewiński, A. Karwacki, Wyższa Szkoła Pedagogiczna im. J. Korczaka, Warszawa 2015.

Grewiński M., Kamiński S., Obywatelska polityka społeczna, WSP-TWP, Warszawa 2007.

Hausner J., Ekonomia społeczna jako kategoria rozwoju, [w:] Ekonomia społeczna a rozwój, red. J. Hausner, Małopolska Szkoła Administracji Publicznej,UE w Krakowie, Kraków 2009.

Hausner J., Ekonomia społeczna jako sektor gospodarki, „Ekonomia Społeczna” nr 1, 2007.

Hausner J., Ekonomia społeczna. Konceptualizacja, [w:] Ekonomia społeczna a publiczne stużby zatrudnienia w Polsce - zasady, perspektywy i kierunki wspólpracy, red. S. Mazur, A. Pacut, FISE, Warszawa 2008.

Herbst K., Perspektywy ekonomii społecznej, „Ekonomia Społeczna” nr 1(6), 2013.

Karwacki A., Glińska-Neweś A., Innowacyjność w podmiotach ekonomii społecznej w Polsce. Studium jakościowe, „Ekonomia Społeczna” nr 2, 2015.

Komorska M., Strategie rozwoju polityki społecznej województwa lubelskiego na lata 2014-2010, „Polityka Społeczna” nr 10, 2014.

Kożuch A., Książek E., Spótdzielnia socjalna jako forma przedsiębiorstwa społecznego, „Pragmata Tes Oikonomias”, „Prace Naukowe Akademii im. Jana Długosza w Częstochowie" z. VIII, 2014.

Krajowy Program Rozwoju Ekonomii Społecznej. Projekt, Warszawa 2012.

Kulesza E., Lokalna polityka społeczna, Centrum Rozwoju Zasobów Ludzkich, Warszawa 2013. 
Kurzynowski A., Związki polityki społecznej zpolityka gospodarcza, [w:] Polityka społeczna, red. A. Kurzynowski, Oficyna Wydawnicza SGH, Warszawa 2001.

Lewandowska-Bratek J., Współczesna gospodarka społeczna jako odpowiedź na niezaspokojone potrzeby społeczne Polaków, „Studia Oeconomica Posnaniensia” nr 7(3), 2015.

Łącka I., Problemy oceny efektywności podmiotów ekonomii społecznej, „Prace Naukowe UE we Wrocławiu" nr 395, 2015.

Miżejewski C., Polityka społeczna wobec sektora ekonomii społecznej, „Ekonomia Społeczna. Teksty" nr 21, 2006.

Miżejewski C., Polityka społeczna wobec sektora ekonomii społecznej, [w:] Raport otwarcia projektu „W poszukiwaniu polskiego modelu ekonomii społecznej”, FISE, Warszawa 2006.

Nisze rynkowe $w$ obszarze wspólpracy podmiotów ekonomii społecznej i jednostek samorzadu terytorialnego w powiecie braniewskim - raport z badań, red. M. Łojko, OWIES, Elbląg 2014.

Orczyk J., Ekonomia społeczna a polityka społeczna, [w:] Wokół ekonomii społecznej, red. M. Frączek, J. Hausner, S. Mazur, Małopolska Szkoła Administracji Publicznej, UE w Krakowie, Kraków 2012.

Porównanie koncepcji wsparcia rozwoju ekonomii społecznej na poziomie regionalnym i krajowym na podstawie wieloletnich regionalnych planów działań na rzecz promocji i upowszechnienia ekonomii społecznej oraz rozwoju instytucji sektora ekonomii społecznej i jej otoczenia $w$ regionie oraz projektu Krajowego Programu Rozwoju Ekonomii Społecznej, Ekspertyza, Szczecin 2013.

Płonka M., Ekonomia społeczna a koncepcje polityki społecznej państwa. Model polski, „Ekonomia Społeczna” nr 2, 2015.

Regionalny Program Rozwoju Ekonomii Społecznej w województwie świętokrzyskim do roku 2020, Urząd Marszałkowski województwa świętokrzyskiego, ROPS, Kielce 2016.

Sadowski T., Ekonomia społeczna $w$ Polsce - nowe perspektywy w przeciwdziałaniu wykluczeniu społecznemu, „Rynek Pracy” nr 3, 2005.

Szarfenberg R., Definicje polityki społecznej, http://rszarf.ips.uw.edu.pl/pdf/definicjeps.pdf

Toczyski W., Niezborności ekonomii społecznej? Rola i miejsce ekonomii społecznej w programach operacyjnych, „Trzeci Sektor” nr 9, 2007.

Wygnański K., Frączak P., Ekonomia społeczna w Polsce - definicje, zastosowania, oczekiwania, wątpliwości, „Ekonomia Społeczna. Teksty” nr 1, 2006.

Wytyczne Ministra Pracy i Polityki Społecznej z dnia 17 maja 2011 r. do przygotowania i realizacji wieloletniego regionalnego planu działań na rzecz promocji i upowszechnienia ekonomii społecznej oraz rozwoju instytucji sektora ekonomii społecznej i jej otoczenia $\mathrm{w}$ regionie.

http://rynekpracy.org/x/430423 


\section{Social economy and the challenges of social policy: in search of correspondences and common areas}

The aim of the article is to present the relations between social economy and social policy as well as to identify the main challenges in the sphere of mutual relations. The main thesis of the article is contained in the statement that the social economy sector is an important instrument for the implementation of social policy, so far insufficiently appreciated and applied in its activities. Social economy, because of its current validity and defined priorities in social policy, deserves a systematic and in-depth research as well as practical application. This paper comprises theoretical considerations presented on the basis of the source literature.

Keywords: social economy, social policy, cooperation, integration.

\section{L'économie sociale et les défis de la politique sociale - à la recherche des correspondances et des espaces communs}

Le but de l'article est de présenter les relations entre l'économie sociale et la politique sociale, ainsi que d'identifier les principaux défis dans le domaine des relations réciproques. La thèse principale de l'article est contenue dans la déclaration suivant laquelle le secteur de l'économie sociale est un instrument important pour la mise en œuvre de la politique sociale, à ce jour insuffisamment reconnu. L'économie sociale, en raison de sa validité actuelle et ses priorités telles qu'elles sont définies dans le domaine de la politique sociale, mérite non seulement une approche systématique et une analyse approfondie, mais également une mise en pratique. Le présent document comprend des considérations théoriques fondées sur les sources bibliographiques.

Mots-clés: économie sociale, politique sociale, coopération, intégration. 


\section{Социальная экономика и проблемы социальной политики - в поисках взаимоотношений и общих областей}

Цель статьи - представить отношения между социальной экономикой и социальной политикой, а также выявить главные проблемы в сфере их взаимоотношений. Основной тезис статьи состоит в том, что сектор социальной экономики является важным инструментом реализации социальной политики, до сих пор недооцениваемым и недостаточно используемым. Социальная экономика в силу своей актуальности и приоритетов в области социальной политики заслуживает как систематических и углубленных исследований, так и практического применения. Статья содержит теоретические соображения, сформулированные на основании проведенного обзора литературы.

Ключевые слова: социальная экономика, социальная политика, сотрудничество, интеграция. 